ISSN: 1641-4713; e-ISSN: 2081-1160

DOI: https://doi.org/10.36551/2081-1160.2020.26.111-134

\title{
Caminhos dos sentidos: penitência e alaridos na Romaria do Senhor dos Passos de São Cristóvão (Brasil, 1903-1978)
}

\author{
Paths of the senses: Penance and howls in Our Lord's of the Steps \\ pilgrimage in São Cristóvão (Brazil, 1903-1978)
}

\author{
Magno Francisco de Jesus Santos \\ Universidade Federal do Rio Grande do Norte, Brasil \\ ORCID iD: https://orcid.org/0000-0002-2218-7772 \\ E-mail:magnohistoria@gmail.com
}

Recepción: 25.03.2019

Aprobación: 4.04.2020

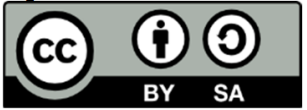

Resumo: A procissão dos Passos na cidade de São Cristóvão é considerada a principal solenidade religiosa de Sergipe, estado do Nordeste brasileiro. Desde o século XIX, na segunda semana da Quaresma, a cidade passava por um período de júbilo, regozijava com romeiros se deslocando dos mais diversos recônditos no intuito de cumprir sua desobriga e renovar seus pedidos. Nessa pesquisa, o objeto é a reinvenção dessa romaria, provocando conflitos e inquietações entre diferentes segmentos sociais que tentaram se apropriar do evento no período entre 1903, ano da chegada dos frades alemães à cidade e 1978, ano da extinção da Ordem Terceira do Carmo. A pesquisa documental pauta-se nos registros produzidos pelo clero (livros de tombo), intelectuais (imprensa), moradores (entrevistas), registros fotográficos e memorialistas. Com isso, busca-se analisar a construção de diferentes representações sobre a celebração e as tensões sociais. O principal conflito ocorreu entre os membros da antiga Ordem Terceira do Carmo, organizadora da romaria, e os frades franciscanos oriundos da Alemanha, que a partir de 1903 assumiram a Paróquia Nossa Senhora da Vitória e tentaram promover o processo de reforma devocional, combatendo as práticas devocionais tidas como inadequadas e o poder dos leigos na celebração. Essa querela envolveu religiosos, leigos, políticos republicanos, romeiros das camadas populares, membros das irmandades e intelectuais preocupados com os efeitos da modernização do estado e com a destruição das tradições. O conflito perdurou até 1978, quando a Ordem Terceira do Carmo, organizadora da procissão, foi extinta pelo arcebispo de Aracaju, Dom Luciano Duarte e foi substituída pela Associação Nossa Senhora do Carmo, presidida pelo pároco.

Palavras-chave: romaria, intelectuais, reforma devocional católica, conflito religioso, penitência. 


\begin{abstract}
The Passos procession in the city of São Cristóvão is considered the main religious ceremony in the Sergipe state in Northeast Brazil. Since the nineteenth century, in the second week of Lent, the city has gone through a period of joy, rejoicing with pilgrims moving from the most diverse corners in order to fulfill their release and renew their requests. In this research, the object is the reinvention of this pilgrimage, causing conflicts and concerns among different social segments that tried to appropriate the event in the period between 1903, the year of the arrival of the German friars in the city and 1978, the year of the extinction of the Third Order of Carmel. Documentary research is based on the records produced by the clergy (tumble books), intellectuals (press), photographic records and memorialists. With this, we seek to analyze the construction of different representations about the celebration and social tensions. The main conflict occurred between the members of the former Third Order of Carmo, organizer of the pilgrimage, and the Franciscan friars from Germany, who in 1903 took over the Parish of Nossa Senhora da Vitória and tried to promote the reform of the devotional process, combating both practices considered inadequate and the influence of the laity in the celebration. This quarrel involved religious and lay people, republican politicians, pilgrims from popular social classes, members of brotherhoods and intellectuals concerned with the effects of the modernization of the state and the destruction of traditions. The conflict lasted until 1978, when the Third Order of Carmo, organizer of the procession, was extinguished by the Archbishop of Aracaju, Dom Luciano Duarte and was replaced by the Nossa Senhora do Carmo Association, chaired by the parish priest.
\end{abstract}

Keywords: pilgrimage, intellectuals, Catholic devotional reform, religious conflict, penance.

Pôr do sol do segundo domingo da Quaresma de 1975. O sino da igreja da Ordem Terceira do Carmo anunciava o fim da procissão do Encontro com dobres fúnebres. Nas ruas estreitas de São Cristóvão, o fremir de romeiros vestidos com túnicas roxas que se deslocavam apressados, entre empurrões e frenesis diante da charola com o Senhor dos Passos, na tentativa de olhar nos "olhos vivos da imagem". Disputas acirradas no entorno da charola com promesseiros gratos, jogando suas túnicas e almejando conseguir um pedaço das fitinhas deixadas nas mãos da imagem. Outros romeiros desciam apressados pelas ladeiras para pegar os caminhões pau-de-arara para retornar a seus lares. Era o fim de mais uma Festa de Passos. Aos poucos, a cor roxa dos devotos diluía-se nas ruas da primeira capital de Sergipe e o cheiro de incenso dissipava-se no ar.

Enquanto os romeiros seguiam para seus lares distantes, os membros da Ordem Terceira do Carmo calculavam o legado da festa maior da cidade. As esmolas deixadas pelos romeiros eram uma importante fonte de arrecadação da principal confraria de Sergipe. Com o esvaziar da Praça do Carmo, as charolas com o Senhor dos Passos e Nossa Senhora da Soledade eram transportadas para o interior do Carmo Pequeno. Mas as atenções não estavam voltadas para as imagens. Naquele ano, havia uma tensão rondando os bastidores da tradicional procissão. Havia silenciamentos e ausências que inquietavam os observadores mais atentos. 
Do outro lado do Carmo, na imponente igreja matriz Nossa Senhora da Vitória, era realizada a última missa do dia com os dois sacerdotes convidados para a solenidade. Padre João e Frei Albano celebravam a Eucaristia na ausência do vigário da paróquia, mas sem deixar de estarem atentos ao que ocorria. A celeuma da principal solenidade católica de Sergipe estava em seus momentos finais, mas a repercussão ainda perduraria por muito tempo.

No mês seguinte, o vigário da Paróquia Nossa Senhora da Vitória retornou a seu posto e, de imediato, procurou saber com os sacerdotes que o substituiu como foi o decorrer das celebrações em louvor ao Senhor dos Passos. Em seguida, o vigário franciscano tratou de registrar no livro de Tombo as informações que ouvira e pincelou as folhas do velho livro com um tom de ironia:

Depois da festa de N. Sra. D'Ajuda de Itaporanga o vigário viajou de férias. Uma vez que estávamos de férias não houve nada de importante para anotar a não ser a festa do Sr. dos Passos. Os romeiros, como sempre vem pagar as suas promessas e deixar as esmolas para a quadrilha de "irmãos" do Carmo. Neste ano Pe João, Frei Albano e D. Adriano Hipólito estiveram aqui. Os dois primeiros por ocasião da festa. Dizem que a cidade ficou repleta de romeiros durante aqueles dias. E assim passou o segundo mês do ano. (Tombo, 1979, p. 531)

Anotações perturbadoras. Frei Martinho Fluanques, franciscano e vigário de São Cristóvão, apresentou no mesmo registro duas facetas da romaria de penitência ao Senhor dos Passos: de um lado, a multidão de romeiros que adentrou a cidade no intuito de realizar o pagamento de promessas ao santo de devoção. Do outro, os membros da Ordem Terceira do Carmo, principais organizadores do evento religioso e apresentados pelo pároco como integrantes de uma quadrilha que tinha como prioridade recolher as esmolas deixadas pelos fiéis.

Partindo dessa situação, duas questões emergem: a primeira remete ao momento da Festa de Passos, no qual o pároco esteve ausente em decorrência do gozo das férias. $\mathrm{O}$ questionamento se refere aos motivos que fizeram com que o vigário escolhesse sair de férias justamente no período de maior agitação da paróquia, com a realização da principal e mais tradicional solenidade religiosa de Sergipe. O que teria motivado Martinho Fluanques a se afastar das celebrações do Senhor dos Passos no seu segundo ano de paroquiato?

O segundo ponto a ser observado é em relação a forma pela qual o vigário tratou os membros da Ordem Terceira do Carmo de São Cristóvão, considerada a mais importante de Sergipe desde o oitocentos. O termo "quadrilha de irmãos" demonstra que existia uma possível animosidade na convivência entre o pároco e os terceiros do Carmo. A cidade que era considerada pelos cronistas e memorialistas a capital religiosa ou a Jerusalém Sergipana estava vivenciando dias de turbulências. 
Tais agitações em torno da devoção ao Senhor dos Passos na cidade de São Cristóvão já ocorria há alguns decênios. Desde os anos sessenta do século XX que a procissão vinha recebendo críticas cada vez mais severas pelo clero da paróquia, demonstrando que as manifestações públicas de fé e sacrifício não agradavam aos organizadores institucionalizados. Em 1969, o também franciscano Afonso Shomaher teceu a seguinte preocupação sobre a solenidade de Passos:

No dia 2 de março celebrou-se a grande festa tradicional do Sr. dos Passos. Parece que o número do povo aumenta de ano em ano. Mas infelizmente não se encontrou ainda um caminho para dar a festa um cunho pastoral. O sermão do Encontro fez o Vigário Carvalho, reitor do Colégio Arquidiocesano - os sermões quaresmais fez o frei Henrique com muito entusiasmo. (Tombo, 1979, p. 480)

Como se pode perceber, existia uma preocupação do clero local em controlar a festa religiosa, ou seja, de fazer com que a solenidade se tornasse mais próxima do modelo de religiosidade adotado pela Igreja Católica. No entanto, no referido documento não fica explícito o que teria provocado o afastamento entre o clero e os membros da Ordem Terceira do Carmo. Em alguns momentos o conflito parecia ser apenas uma questão de interesses sobre as esmolas deixadas pelos romeiros do Senhor dos Passos, como destaca o primeiro relato do vigário Martinho Fluanques a respeito da procissão dos Passos, logo após a sua chegada a paróquia.

Em março tomava parte nas pregações do Carmo Pequeno. Era a festa do Senhor dos Passos. No dia teve muita gente, procissão de noite e no dia seguinte, um domingo, o vigário acompanhou a procissão olhando tudo. Assistiu como os irmãos do Carmo trabalhavam com o Sr. dos Passos para tirar as esmolas, ajuntar as velas e objetos que o povo dar. O povo tem devoção ao Sr. dos Passos e quem lucra são os irmãos. Vida espiritual não tem e nem tão pouco convidam o vigário para assistir a uma reunião deles. O povo dar as suas esmolas e parecem que dividem o bolo entre si. É esquisito a maneira dos irmãos do Carmo procederem. Da a impressão de que são intocáveis. (Tombo, 1979, p. 520)

O registro do vigário de São Cristóvão, um mês após sua chegada a Paróquia Nossa Senhora das Vitórias demonstra uma relação de animosidade. Entretanto, não podemos entender as tensões na solenidade do Senhor dos Passos da cidade de São Cristóvão somente pelo viés dos interesses econômicos. Os impasses têm muito mais a revelar. Os conflitos podem ser vistos como mais uma faceta da complexa rede que envolve a trajetória histórica da mais tradicional procissão católica do estado de Sergipe.

Nos bastidores da solenidade, a instituição organizadora estava em crise. A década de 70 do século XX marcou o declínio da Ordem Terceira do Carmo. Em São Cristóvão, os carmelitas já haviam deixado o convento no século XIX, ${ }^{1}$

\footnotetext{
${ }^{1}$ Ao longo do século XIX, o governo imperial brasileiro instituiu uma política de restrição às ordens religiosas, com a proibição do ingresso de novos religiosos nas ordens existentes no país. Com isso, os conventos franciscanos, carmelitas, beneditinos e mercedários foram paulatinamente fechados. Os templos ficaram, até certo ponto, mantido pelas respectivas ordens terceiras, ou seja, sob o controle de leigos.
} 
mas permitiram a manutenção da Ordem Terceira com nomeações ocorridas em visitas esporádicas que os carmelitas realizavam à cidade. Contudo, essas visitas cessaram e o número de irmãos ficou restrito. Em meados da década existiam na cidade dois grupos de terceiros: os que assumiram o cargo por meio de nomeações dos carmelitas (em menor número) e os que foram empossados por nomeações dos párocos da cidade (a maioria). Isso fez criar uma situação de hostilidade dentro da ordem e a tornou mais vulnerável diante do clero reformador.

Paulatinamente, a secular ordem perdia seu prestígio diante do clero. A crise aguçou com a morte do último terceiro nomeado pelos carmelitas, Domingos Sobral do Rosário. Com a morte deste as intervenções do clero aumentaram e gerou uma tensão na Ordem e nos bastidores da Festa de Passos. Por alguns meses as portas do Carmo Pequeno ficaram trancadas (Monteiro, 2003). A intervenção da alta hierarquia do clero sergipano se fez necessário para solucionar os impasses.

Para entender as sucessivas críticas tecidas pelo clero cristovense à solenidade de Passos é necessário investigar as transformações litúrgicas das celebrações ocorridas no período no período entre os dois concílios do Vaticano. As manifestações populares do catolicismo do Brasil passaram por um processo de renovação e isso muitas vezes acarretou em conflitos entre o clero reformador e os leigos, até então detentores de grande poder nas celebrações de cunho popular. Nesse sentido, a procissão dos Passos de São Cristóvão poderia estar passando por esse processo, com a crise gerada no seio da Ordem Terceira do Carmo, que no final em 1978 foi oficialmente extinta e substituída pela Associação Nossa Senhora do Carmo, sob a tutela do Arcebispo de Aracaju, D. Luciano Cabral Duarte.

Com isso, neste artigo tem-se como objeto a reinvenção dessa romaria, provocando conflitos e inquietações entre diferentes segmentos sociais que tentaram se apropriar do evento no período entre 1903, ano da chegada dos frades alemães à cidade e 1978, ano da extinção da Ordem Terceira do Carmo. A pesquisa documental pauta-se nos registros produzidos pelo clero (livros de tombo), intelectuais (imprensa), moradores (entrevistas), registros fotográficos e memorialistas. Tais registros documentais possibilitam a análise acerca da construção de diferentes representações sobre a celebração e as tensões sociais. O principal conflito ocorreu entre os membros da antiga Ordem Terceira do Carmo, organizadora da romaria, e os frades franciscanos oriundos da Alemanha, que, a partir de 1903, assumiram a Paróquia Nossa Senhora da Vitória e tentaram promover o processo de reforma devocional, combatendo as práticas devocionais tidas como inadequadas e o poder dos leigos na celebração. 


\section{A ROMARIA DO SENHOR DOS PASSOS: HISTÓRIAS E INQUIETAÇÕES}

Os impasses entre clero e leigos ocorreram em torno da mais importante celebração católica de Sergipe. A procissão de Senhor dos Passos, também chamada de Festa de Passos, desde o século XIX, já era conhecida como o evento religioso sergipano com maior poder aglutinador de devotos. Práticas penitenciais, romeiros e estética barroca faziam parte das celebrações, que reviviam pelas ruas estreitas da cidade os últimos passos de martírios de Cristo.

Por ser uma celebração que envolvia a participação de milhares de romeiros e parte considerável da elite açucareira local, ${ }^{2}$ a procissão dos Passos atraiu, ao longo do tempo, o interesse de muitos historiadores memorialistas. A intelectualidade sergipana se debruçou sobre a cerimônia de penitência que revelava pompa e práticas penitenciais, além de aglutinar diferentes segmentos da sociedade sergipana em cortejos que seguiam o ritmo dos sinos. Foram esses intelectuais que produziram registros relevantes que podem auxiliar o trabalho do historiador de reconstituição das celebrações festivas e penitenciais.

Por meio desses documentos acerca da procissão do Senhor dos Passos na cidade de São Cristóvão, a partir das percepções pelos memorialistas por meio dos sentidos, tornou-se possível compreender os conflitos inerentes à solenidade e suas relações com o movimento de renovações das práticas devocionais estimuladas pelo Concílio do Vaticano II. É importante lembrar que os conflitos também podem ser percebidos por meio dos diferentes sentidos e que algumas das prerrogativas criticadas pelo clero de São Cristóvão estavam associadas a questões do ritmo, do silêncio, dos murmurinhos dos irmãos terceiros, dos odores, empurrões e visual (Freyre, 2000). Os religiosos queixavam-se do ritmo acelerado da procissão, da prática devocional dos romeiros em jogar "as mortalhas" molhadas de suor na imagem, do distanciamento do catolicismo reformado.

$\mathrm{Na}$ festa de Passos, os holofotes poderiam estar direcionados às imagens do Senhor dos Passos e de Nossa Senhora da Soledade, mas as atenções do clero estavam direcionadas a outros ângulos: a destituição da Ordem Terceira. Partindo dessa assertiva, pode-se dizer que tanto os conflitos dos bastidores, como a própria

\footnotetext{
${ }^{2}$ A solenidade do Senhor dos Passos é realizada em vários municípios de Sergipe, com destaque para Aracaju, Itaporanga d'Ajuda, Estância, Rosário do Catete, Laranjeiras, Divina Pastora, Santo Amaro das Brotas e Maruim, onde é padroeiro do município. Entretanto, é na cidade de São Cristóvão que a procissão atrai o maior número de romeiros, inclusive parte considerável da elite política estadual. Sobre a participação da elite açucareira e dos anônimos na procissão dos Passos de São Cristóvão pode ser consultado o artigo de Verônica Nunes e Magno Santos "Na trilha dos Passos do Senhor: a devoção ao Senhor dos Passos de São Cristovão/SE" publicado na Revista da Fapese (2005).
} 
celebração pública podem ser analisadas por meio dos sentidos. Odores, toques, ruídos, sabores e vozes podem ser utilizados como fio condutor na compreensão do objeto histórico (Duvinaud, 1983). Com isso, evidenciou-se a leitura da procissão dos Passos de São Cristóvão por meio dos sentidos, com ênfase para os impasses entre o clero e os irmãos terceiros do Carmo na organização da solenidade.

Até o ano de 1903, a Paróquia Nossa Senhora da Vitória estava sob o controle do clero secular, destacando-se nomes como o do vigário Barroso, que ao longo da segunda metade do século XIX, exerceu grande influência na vida social, política e cultural da cidade. Ele foi um dos responsáveis por impregnar a solenidade dos Passos de aspectos dramáticos, teatralizados.

Nos idos de 1903, a paróquia foi entregue aos franciscanos, ${ }^{3}$ que tentaram, paulatinamente, propor e exercer algumas alterações nos festejos penitenciais de Passos. Partindo dessa acepção, é relevante o papel exercido pelos frades franciscanos oriundos da Saxônia na reformulação da Procissão dos Passos, a partir do momento em que os mesmos assumiram a paróquia e tentaram engendrar o controle institucional sobre a romaria.

1978 marcou o ápice e o desfecho do conflito entre os franciscanos e os irmãos terceiros do Carmo. Nas semanas que antecederam a romaria, a Igreja do Senhor dos Passos foi fechada com dois cadeados: um dos terceiros, outro do pároco. Era um grande entrave, no qual nenhum dos dois agentes recuavam e a romaria estava ameaçada. Com isso, ocorreu a intervenção da Arquidiocese de Aracaju, por meio da atuação mediadora de Dom Luciano José Cabral Duarte, que decretou a extinção da Ordem Terceira do Carmo e reuniu os seus antigos integrantes em uma nova organização, com a fundação da Associação Nossa Senhora do Carmo, sob a batuta de D. Luciano Cabral Duarte e frei Matinho Fluanques, pároco da freguesia. Assim, a romaria do Senhor dos Passos em São Cristóvão entrou em uma nova fase, sofrendo maior intervenção institucional.

É importante ressaltar que no universo desse período, constituído a partir de episódios atrelados à trajetória histórica do próprio objeto, ocorreram eventos de suma importância no seio da Igreja Católica, como o Concílio do Vaticano II (1964-1967). Portanto, essa investigação não se deteve apenas na compreensão de uma solenidade religiosa em seu âmbito interno, mas também inseriu os impasses da esfera religiosa dos Passos no contexto das reformas desencadeadas na Igreja Católica após o Concílio do Vaticano II, com ênfase no fortalecimento do controle do clero.

\footnotetext{
${ }^{3}$ A Ordem de São Francisco em Sergipe era constituída pelos frades oriundos da Província Franciscana da Santa Cruz da Saxônia, Alemanha.
} 
Trata-se, portanto, de uma investigação de História Social da Cultura, pois se debruçou sobre as transformações de uma celebração religiosa que envolve diferentes segmentos sociais e possui importantes elementos simbólicos. A festa de Passos pode ser observada como uma fresta reveladora tanto dos aspectos da mentalidade barroca, como as práticas sacrificiais, pompa e elementos teatrais, como também as ações reformadoras provenientes dos concílios na esfera de uma romaria de âmbito local.

Com essa investigação, os elementos simbólicos da solenidade e os conflitos entre o clero e leigos foram desnudados. Diferentes segmentos sociais e sujeitos emergiram no cenário festivo dos Passos e despertou o interesse da intelectualidade sergipana, que buscou registrar a solenidade de diferentes ângulos, valorizando aspectos sensitivos na percepção da realidade observada. A pesquisa sobre os impasses entre o clero e os leigos, em relação ao controle da solenidade do Senhor dos Passos em São Cristóvão, teve como pano de fundo a própria romaria e tentou reconstituir os cenários das celebrações ao longo do período (1903-1978). Nessa reconstituição o enfoque se deteve nos aspectos dos sentidos. As diferentes acepções da realidade foram alocadas nos registros históricos, na tentativa de realizar uma leitura das procissões penitenciais por meio dos ruídos, odores, toques, falas e visões. A estética barroca da solenidade foi esmiuçada por uma nova abordagem: a dos sentidos como expressão da realidade observada.

\section{OS SENTIDOS DA ROMARIA DO SENHOR DOS PASSOS}

A solenidade de Nosso Senhor dos Passos na cidade de São Cristóvão pode ser percebida de diferentes formas. Devido à grande contingência de devotos de procedências e segmentos sociais distintos, a romaria dos Passos apresenta um vasto leque propiciador de reflexões (Tuner, 1986). Um dos percursos pelos quais o pesquisador pode enveredar é o dos elementos registrados a partir da sensibilidade perceptiva das testemunhas oculares da celebração.

Os ruídos do tempo são permanências, continuidades, sinais deixados por outras gerações, muitas das vezes imperceptíveis para os olhares e ouvidos desatentos. Os indícios da devoção ao Senhor dos Passos não estão documentados exclusivamente nos registros escritos, pois também podem ser detectados por meio da análise minuciosa de imagens, do espaço, da arquitetura ou mesmo nas entrelinhas dos textos escritos e das oralidades (Ginzburg, 1987).

Ao observar a imagem do Senhor dos Passos de forma mais atenta, pode ser percebido que ela traz os sinais das romarias realizadas ao longo dos anos. 
A descoberta da imagem como testemunho da devoção ocorreu graças à observação das celebrações nos últimos anos, pois tornou-se possível constatar que os romeiros ao chegar à Igreja do Carmo, cumpriam um trajeto comum, passando sob as charolas do Senhor dos Passos e de Nossa Senhora da Soledade, para enfim, tocar demoradamente nas mãos da imagem de Passos.

Figura 1: CARTÃo-Postal da SOlEnidade de Passos. Senhor dos Passos e Nossa Senhora DA SOLEDADE, 1978

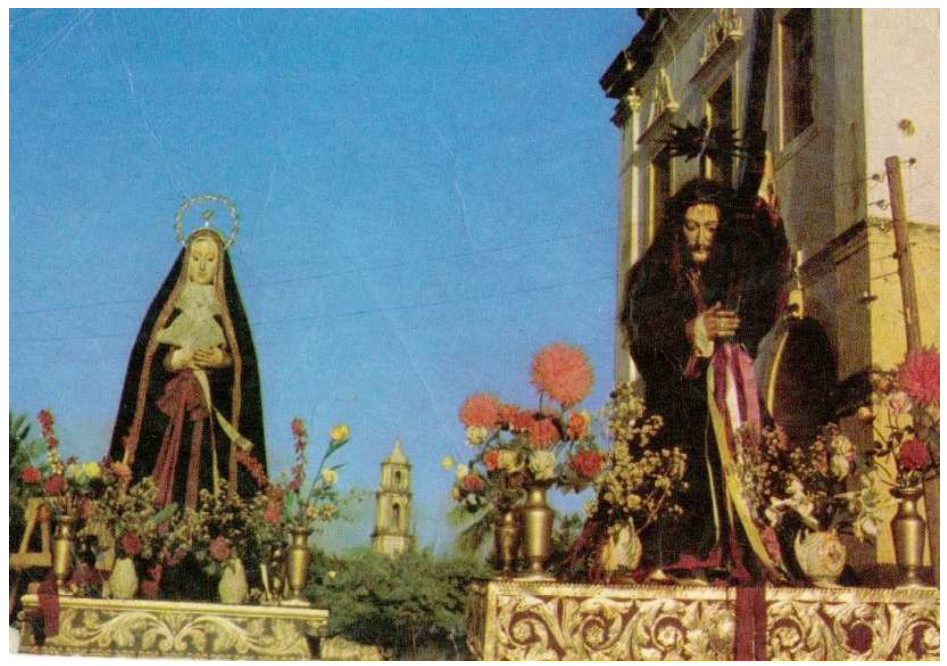

Fonte: Acervo Josefa de Jesus Santos.

Trata-se da ocasião em que o devoto dialogava aos pés da charola, rendendo-lhe agradecimentos e renovando os seus pedidos por graças. O toque contrito nas mãos da imagem representava a busca do devoto por bênçãos, a renovação do homem religioso, a intimidade romeiro/santo. A observação participante do evento atual serviu para nos instigar, fazendo-nos procurar analisar de forma mais detalhada o cenário montado na charola do Senhor dos Passos. ${ }^{4}$

A repetição da tradição, renovada a cada ano no santuário, não passou imune: deixou suas marcas impregnadas nas imagens devocionais, registrou a passagem dos promesseiros ao longo do tempo. Um desses sinais é a mão enegrecida do Senhor dos Passos, causada, provavelmente, pelos toques contínuos dos romeiros. $\mathrm{O}$ enegrecimento da mão da imagem reflete o elevado número de devotos que todos os anos buscavam se aproximar do Senhor dos Passos. São

\footnotetext{
${ }^{4} \mathrm{Na}$ charola do senhor dos Passos estavam representados os sete passos da Paixão, na ornamentação prateada. Os artefatos de prata foram uma aquisição do governo provincial de Sergipe em 1848.
} 
elementos de uma religiosidade barroca, de um catolicismo rústico, na qual a devoção era tecida sob o campo da intimidade entre o devoto e o campo sagrado.

A mão enegrecida da imagem reflete o elevado número de devotos que todos os anos buscavam aproximar-se do Senhor dos Passos. Podemos observar a mão da posição inferior, atualmente, muito mais escura do que a superior. A partir da reflexão da diferença de tonalidades das mãos da imagem, podemos inferir a proporção devocional direcionada ao Senhor dos Passos. Contudo, as diferenças de tonalidades não constituem os únicos indícios a respeito da solenidade de Passos no período estudado. Existem outras vozes que rompem o silêncio do tempo. Um costume permeou a trajetória devocional da imagem na cidade e permanece nos dias atuais, o depósito devocional de ramos de manjericão sobre a charola nas semanas posteriores a procissão.

Essa prática devocional é reveladora, haja vista a representatividade dos referidos ramos. As flores do manjericão são conhecidas em alguns estados do Brasil, como São Paulo, por "flores do Senhor dos Passos", provavelmente em decorrência de sua cor arroxeada. O propósito principal dessa prática religiosa era benzer os referidos ramos para usá-los em situações de emergência, isto é, consistia em um mecanismo de prorrogar a proximidade com a realidade sacra.

Todavia, um dos principais aspectos da solenidade de Passos é a sonoridade. Dos primeiros instantes, ao final da romaria, os ruídos são transformados em elementos de sacralidade, de demarcação do tempo diferenciado, do momento extraordinário (Eliade, 2001). A sonoridade apresenta-se na romaria por meio dos cânticos dos passos em latim (recordatus), das tarantanas dos sinos, dos lamentos dos indigentes e até mesmo do silêncio, que permeia muitos discursos de memorialistas. No estudo das manifestações religiosas de outrora, a sonoridade pode ser compreendida como um instrumento mediador entre passado e presente. Ao se propagarem pelo espaço, os elementos sonoros tornam-se inacessíveis (Claval, 2001). Contudo, os ecos da sonoridade permanecem ao serem registrados nas falas das testemunhas. Por ser um mecanismo de percepção da realidade pouco habitual dentro das Ciências Humanas, na maioria das vezes, tais registros passam despercebidos nas leituras dos pesquisadores (Thompson, 2007). Os sussurros do passado parecem ainda não ter conquistado os ouvidos dos historiadores.

Na solenidade de Passos, um dos principais aspectos caracterizadores era a sonoridade. Os ruídos da celebração estão consignados em documentos de diferentes origens, como notas de jornais, obras memorialísticas, sinos e fotografias. São múltiplos depoimentos que registraram flagrantes nos quais predomina- 
vam o mais absoluto silêncio. A partir destas vozes do passado, torna-se possível reconstituir o universo etnográfico da solenidade de Passos.

A solenidade de Passos atraia devotos de diferentes pontos de Sergipe. A afluência de romeiros percorrendo as estradas de São Cristóvão chamava a atenção de cronistas e da imprensa. O trajeto era marcado pela penitência e pela descontração. Através de registros noticiados na imprensa sergipana na década de 1910, podemos perceber flagrantes do cotidiano dos romeiros nos caminhos da penitência de Passos, como demonstra a seguinte nota:

Como todos os anos celebrar-se-ão na tradicional cidade de S. Christovam os officios da Festa de Passos. A afluência à antiga metrópole sergipana sempre foi e é ainda considerável de pessoas de todos os pontos do Estado, notadamente daqui da Capital.

Outrora a grande romaria era feita a pé em dias seguidos, enchendo-se a velha estrada de povo, preferindo muita gente ir descansando às sombras das arvores, fazendo lunchs appetitosas que as saboreavam os goles da boa água do Pitanga. Caminhos saudáveis proporcionavam uma viagem agradável até as portas da velha Jesusalém sergipana povoada de templos catholicos, muitos carcomidos pelo decorrer do tempo. Ainda hoje, apezar de termos caminho de ferro, muita gente prefere ir 'puxando na bota'. (Diário da Manhã, 19 mar. 1916)

A nota jornalística desvenda múltiplos aspectos da longa jornada dos romeiros a caminho do santuário de Passos, a "Jerusalém sergipana". Revela aspectos sensoriais do trajeto dos romeiros, principalmente ao se referir às paradas para descanso às margens do rio Pitanga. $\mathrm{O}$ depoimento expressa dois sentidos pouco explorados pela historiografia como elementos de percepção da realidade observada. O tato e o paladar estão evidenciados na breve notícia, ao abordar sobre a brisa embaixo das árvores e o sabor das refeições e da água potável do rio Pitanga. Neste sentido, na solenidade de Passos, no período estudado, podemos buscar conhecer os sabores, olhares, falas, toques e ruídos das celebrações religiosas.

Por ser uma celebração de cunho penitencial, a procissão dos Passos no período entre o final do século XIX e o início do século XX estava atrelada ao silêncio e ao dobre fúnebre dos sinos de todas as igrejas da cidade alta. O ápice das práticas penitenciais ocorria no segundo sábado da quaresma, com a procissão do depósito. Durante o dia, os sinos do Carmo e da Ordem Terceira eram tocados, anunciando a referida procissão noturna. No plano simbólico, o dobrar do sino pode ser interpretado como indício da santificação do dia, da ruptura do tempo ordinário e a entrada no tempo sacralizado. Segundo Serafim de Santiago:

No sabbado, durante o dia a Egreja do Carmo era, como ainda hoje, muito visitada pelos romeiros ali existentes. À uma hora e às três da tarde do sabbado, ouvia dobrarem os sinos da Ordem $3^{\mathrm{a}}$ e do Carm

o, annunciando aos fieis a Tradicional procissão à noite, denominada do depósito. Ao toque da Ave-Maria eram repetidos os dobre chamando o povo para o acto da concorridíssima procissão que sahia da Egreja do Carmo; esta maior de São Christovão não comportava o extraordinário número de fiéis que espalhavam-se pela praça do Carmo aguardando a sahida da imponente procissão. (Santiago, 2009, p. 182) 
O depoimento de Santiago é elucidativo ao demonstrar o dobrar dos sinos das duas igrejas e o elevado contingente de romeiros. O sábado da semana de Passos na cidade de São Cristóvão era considerado um dia santificado. O som dos sinos servia para enfatizar a entrada neste tempo mítico. A sacralidade do dia tornava-se evidente tanto por meio da tarantana dos sinos, como pela mudança de comportamento dos moradores, conforme Erundino Prado Júnior, "no dia das festividades alusivas ao Senhor dos Passos, não varria a casa, não podia esbanjarse" (entrevista concedida no dia 17 de agosto de 2006, São Cristóvão).

No sábado à noite, ocorria a procissão de transladação da imagem velada do Senhor dos Passos da Igreja do Carmo para a Matriz. A procissão de caráter penitencial seguia o ritmo dos sinos, que começavam a dobrar no momento da saída da charola, como confirma Santiago:

Chegados junto à charola, ajoelhavam-se todos, e o frade Carmelita recebia das mãos do sacristão a naveta e fazia o incenso, em que os músicos cantavam o versículo - 'Et recordatus est Petrus verbi Domini, sicut dixerat: guia prius quan gallus cantet, tu me mégabis ete'. Findo este cântico, ouvia-se o dobrar dos sinos da egreja $3^{\mathrm{a}}$ e os do Carmo. (Santiago, 2009, p. 183)

A partir da reflexão desses ruídos, que perpassaram as barreiras impostas pelo tempo, podemos compreender a solenidade do Senhor dos Passos em sua complexidade. A documentação referente à solenidade é vasta e diversificada, propiciando múltiplas leituras. A curta jornada dos romeiros na cidade de São Cristóvão era demarcada pela visão, cheiro, sentir e ruídos. Todos esses elementos estavam presentes nas procissões realizadas no segundo final de semana da quaresma de São Cristóvão. Conforme Santiago, na procissão do depósito ficavam:

Junto à charola, o frade Carmelita, o Franciscano e o Sacristão levando o thuribulo de onde sahia a fumaça do aromático benjuim perfumado as ruas por onde passava... encaminhava a procissão até parar a imagem em frente a primeira casa de esquina da rua da Imperatriz, onde se achavam os músicos para cantar o versículo da $1^{\mathrm{a}}$ estação. Em toda a praça do Carmo, rua da Imperatriz e praça da Matriz por onde passava a procissão, estavam illuminadas as fachadas das casas sobrados. O silêncio nesta ocasião não me é possível descrever. Ouvia-se dobrar, os sinos do Amparo, o sonoro grande sino do São Francisco e o da Matriz. (Santiago, 2009, p. 183)

O testemunho do memorialista desenha um cenário complexo da solenidade a partir dos aspectos sensitivos de percepção da realidade. Cheiro, toque, gosto, visão e ruídos permeiam toda a narrativa. Todos esses elementos contribuem na compreensão do objeto estudado, por serem importantes instrumentos perceptivos. Ao sair pelas ruas da cidade, a procissão do depósito era cercada por uma série de aparatos sacralizadores, dos quais podemos destacar o aroma propagado pelo incenso, a iluminação das fachadas, o silêncio dos devotos e o dobrar dos sinos. Com isso, configurava-se um cenário, um território flexível (Claval 
2001), no qual os atores sociais apresentavam-se, com ênfase para o Senhor dos Passos (que ostentava a sacralidade), a elite política e religiosa.

Entre os devotos da sagrada imagem, destacava-se a elite açucareira do Vaza-Barris. Muitos dos senhores dessa zona econômica faziam parte da Ordem Terceira do Carmo e tinham o direito exclusivo de transportar a charola do Senhor dos Passos na procissão do depósito. Com isso, no período entre o final do século XIX e o início do século XX, integravam o cortejo processional "o presidente da Província, Barão da Estância, comendador Sebastião Gaspar de Almeida Botto, coronel Joze Guilherme da Silveira Telles, coronel Domingos Dias Coelho e Mello, Dr. Silvio Anacleto de Souza Bastos e Dr. Simões de Mello" (Santiago, 2009 , p. 182). Entre os nobres sergipanos que tinham devoção ao Senhor dos Passos, destacava-se o Barão da Estância. Segundo consta nos registros sobre a procissão, Antônio Dias Coelho e Mello era um dos primeiros a chegar à Igreja do Carmo para a procissão das velas. O senhor proprietário do Escurial, como prova de devoção e estima ao Senhor dos Passos, doou uma rica túnica e deixou para o mesmo em seu testamento uma apólice de valor considerável e com juros de cinco por cento ao ano. ${ }^{5}$

Os vestígios desta devoção perpassaram o tempo. Na Igreja Matriz de São Cristóvão, ainda hoje podemos encontrar a velha túnica doada pelo barão-devoto. Nela estão evidências das práticas devocionais dos romeiros realizadas ao longo dos anos. O luxo das ornamentações do pomposo manto contrasta com o desgaste imposto pelo tempo e pelos sucessivos toques dos devotos. Neste sentido, a túnica de Passos também pode ser vista como uma fonte histórica de relevância.

No baú da Igreja Matriz encontramos muitas surpresas. Esperávamos ansiosos para ter acesso à vestimenta doada pelo Barão da Estância, no entanto, encontramos uma ampla coleção de vestimentas doadas pelos devotos ao Senhor dos Passos e a Nossa Senhora da Soledade no último século. O elevado número de peças por si só demonstra o poder devocional ao Senhor dos Passos. São vestígios que denotam as práticas devocionais, por meio da doação de vestimentas, como pelo desgaste revelador do toque dos devotos e romeiros.

O final da procissão do depósito era marcado pela concorrência de fiéis tentando tocar e beijar os pés da imagem. Mesmo estando velada, ${ }^{6}$ os romeiros

\footnotetext{
${ }^{5}$ Sobre as apólices deixadas ao Senhor dos Passos, confira o testamento de Antônio Dias Coelho e Mello, Barão da Estância. Testamento. Cartório do $1^{\circ}$ Ofício. São Cristóvão, cx. 11, nº 77.

${ }^{6}$ Provavelmente, a imagem do Senhor dos Passos saía velada na procissão do depósito para representar a perseguição de Cristo pelos soldados romanos, como atestam entrevistados como M. P. Monteiro (entrevista concedida no dia 12 de dezembro de 2003, São Cristóvão) e E. Prado Júnior (Entrevista concedida no dia 17 de agosto de 2006, São Cristóvão). Os moradores da cidade também falam de
} 
esforçavam-se para ter acesso à charola, com o intuito de "conversar" com o santo. As práticas ex-votivas da procissão e o contato entre devoto e santo na solenidade foram assim descritas por dona Marinete:

É... as promessas era assim: feixe de lenda, agora sempre as velas acesas, sempre todo mundo descalço e a vela acesa. Isso não mudou muito não. Agora era o feixe de lenha, depois do feixe de lenha inventaram a roupa roxa (...). Quando termina a procissão, primeiro o santo entrava, mas era aquele chamego, de todo mundo queria beijar o santo e não dava na igreja. Agora, coloca-se o santo lá na frente da igreja, para todo mundo beijar, se despedir Dele, conversar perto. (Monteiro, 2003)

O relato de dona Marinete é enfático e surpreendente por abordar de forma natural a antromorfização da imagem dos Passos, através de termos como "conversar" e se "despedir" dele. O toque e o beijo à imagem refletem a intimidade devoto/sagrado. Este era o momento de renovação dos pedidos por graça e, ao mesmo tempo, de gratidão pelas benesses já alcançadas (Vovelle, 1987). Em diferentes momentos das narrativas, percebemos que o Senhor dos Passos de São Cristóvão não era tratado como uma imagem de culto, mas sim como a real presença encarnada e humanizada do Cristo sofredor. Com a chegada da procissão noturna à Igreja Matriz, a charola era depositada em dois cavaletes ao lado da capela do Santíssimo Sacramento, momento em que se ajoelhavam "os sacerdotes e todo o povo em frente à imagem encerrada” (Santiago, 2009, p. 184).

No dia seguinte, segundo domingo da quaresma, ocorria a imponente procissão do encontro. $\mathrm{O}$ dia era marcado pelo dobrar dos sinos e pelas missas nas principais igrejas da solenidade (Matriz e Carmo). Um dos momentos de maior expectativa ocorria quando o romeiro encontrava a imagem do Senhor dos Passos exposta à veneração. Na ocasião, a troca de olhares, os romeiros observavam firmemente "os olhos vivos do Senhor". Na Matriz, o devoto via então que:

Ali estava elle de joelho em terra no centro da charola, vestido em rica túnica de gorgurão roxo, supportando o pezo do grande madeiro, com aquele rosto venerável, os olhos injectados fitos para o chão, demonstrado a grande agonia cauzada pelo pezo da cruz. (Santiago, 2009, p. 185)

A narrativa de Serafim de Santiago revela o artifício intrínseco na imagem, que fazia com que a interação romeiro/santo fosse aguçada. Estrategicamente, o Senhor dos Passos ficava sobre a charola em uma posição que direcionava o olhar da imagem para os devotos. Essa era mais uma nuança da teatralidade barroca presente na solenidade de Passos.

outra versão, que seria a representação de como a imagem foi achada, nas margens do rio Paramopama, dentro de uma caixa. 
Durante todo o dia, os romeiros ficavam perambulando pelas ruas, visitando familiares e templos até às quatro horas, quando os sinos da Matriz dobravam, convocando os fiéis para a procissão do encontro. Com os primeiros dobres, começavam a chegar os representantes das ordens terceiras, irmandades e confrarias da cidade. Assim, da Igreja do Rosário, desciam anjinhos: do São Francisco, os irmãos terceiros, ${ }^{7}$ assim como da Ordem Terceira do Carmo. Todos eram recebidos pela irmandade do Santíssimo Sacramento, responsável pela Matriz. O momento da saída dos irmãos leigos de suas igrejas de origem era marcado pelo dobrar dos respectivos sinos, aumentando a expectativa dos devotos reunidos na praça. Podemos dizer, então, que a celebração envolvia todas as associações religiosas das principais igrejas da cidade, ritmadas pelo dobre dos sinos.

Com a saída simultânea das duas procissões da Igreja Matriz e do Carmo Pequeno às cinco horas da tarde, todos os sinos dobravam em ritmo fúnebre. No cortejo, estava a cruz processional, a espia com a custódia, os anjinhos do Rosário e o Senhor dos Passos. A procissão seguia até parar no primeiro passo, representado pelo Horto. Com isso, todos paravam para ouvir o primeiro passo, que era acompanhado pela cerimônia do incenso e bênção do passo. No silêncio penitencial, a sacralidade propagava-se pelo aroma do incenso.

Seguindo percursos diferentes, as imagens do Senhor dos Passos e de Nossa Senhora da Soledade seguiam até a Praça São Francisco, local onde se dava "a dolorosa memoração da tragédia da rua da amargura, 'o encontro da formoza filha de Sião com o unigênito filho"” (Santiago, 2009, p. 189). Na praça, era realizada a cerimônia do incenso e a execução do canto do passo. A entrada da imagem do Senhor dos Passos era ritmada pelo dobrar dos sinos de todas as igrejas, como tarantanas fúnebres, isto é, tratava-se de uma marcha para o calvário.

O encontro era visto como um dos momentos culminantes da celebração dos Passos. Nessa ocasião, os elementos da teatralidade barroca eram explorados ao extremo. As palavras inspiradas do padre laranjeirense transportavam o devoto para o tempo mítico da Paixão. Ocorria então a interação entre devoto, clero e sagrado. A Praça São Francisco era transformada em um grande auditório, no qual as atenções estavam voltadas para o sermão do doloroso encontro. Mais uma vez os sentidos refletem as nuanças da solenidade, como podemos observar:

\footnotetext{
${ }^{7}$ Os irmãos terceiros do São Francisco carregavam a charola do Senhor dos Passos na procissão do encontro, cumprindo com o compromisso da referida ordem que dizia "são obrigados os Irmãos terceiros de São Francisco a carregarem a charola do Senhor dos Passos na procissão do $2^{\circ}$ Domingo da quaresma, assim como os irmãos terceiros do Carmo a carregarem a charola da Virgem da Conceição na procissão das Cinzas” (Santiago, 2009, p. 186).
} 
Findo este terceiro cântico, surgia no púlpito o vulto do orador consumado - vigário Joze Gonçalves Barrozo que lançando um olhar prescutador sobre o enorme audictório que enchia a praça, principiava a falar, desenrolando os martyrios e soffrimentos da victima ali presente. O povo já ancioso esperava aquellas palavras inspiradas. Naquelle momento já estavam parados todos os sinos e reinava o completo silêncio, esperando os ouvintes o momento mais tocante d'aquelle acto, o encontro doloroso da Santíssima Virgem com seu unigênito filho em completa afflição na rua da Amargura. (Santiago, 2009, p. 189)

No depoimento acima, percebemos a importância dos elementos sensoriais na solenidade de Passos. $\mathrm{O}$ encontro era permeado pela troca de olhares, pelo sermão e, principalmente, pelo silêncio dos sinos e do público. Os sinos paravam para o momento em que as dores se intensificavam, pois as dores de Cristo com o madeiro somavam-se às dores da Virgem-mãe e dos devotos sofridos e carentes de benesses.

Muitos dos aspectos da realidade passada perderam-se no tempo, tornando-se inaudíveis para nossos ouvidos do presente. Contudo, alguns ruídos da solenidade dos Passos ainda podem ser detectados através da leitura das entrelinhas das evidências históricas. No caso do encontro das imagens do Senhor dos Passos e de Nossa Senhora da Soledade na Praça São Francisco, os resquícios sonoros sobreviveram. O sermão do encontro era marcado pelo silêncio, como podemos constatar:

Á tarde effectuou-se a procissão das imagens de Senhor dos Passos e de Nossa Senhora da Piedade [sic] com um acompanhamento de milhares de pessoas. Pregou o sermão do encontro o illustrado monsenhor Zacharias que prendeu a attenção da enorme multidão, com a sua palavra fácil, cadenciada, clara e eloqüente, fazendo comparações as mais felizes que eram muitas vezes applaudidas, conforme o respeitoso momento e como bem podia divulgar pelos gestos expressivos de muitas physionomias atentas. (Diário da Manhã, 10 mar. 1914)

O silêncio dos devotos durante o sermão do encontro nas primeiras décadas do século XX chega a surpreender. Apesar de haver milhares de romeiros lotando as dependências da Praça São Francisco, as palavras do sacerdote podiam ser ouvidas por todos, mesmo sem haver uso de instrumentos transmissores. Do alto do púlpito portátil, as palavras do orador sacro ecoavam por todo o auditório de fiéis, evocando a emoção da maior parte dos romeiros. Assim, o silêncio é revelador do caráter penitencial da solenidade, no qual a dor do Cristo sofredor era compartilhada com a Mãe e, ao mesmo tempo, confundida com o sofrimento cotidiano dos devotos. Isso pode ser observado no âmbito da cultura visual, com a Figura II. 
Figura 2: SeRmão do Encontro na Praça SÃo Francisco, dÉCADA DE 40 do SÉculo XX

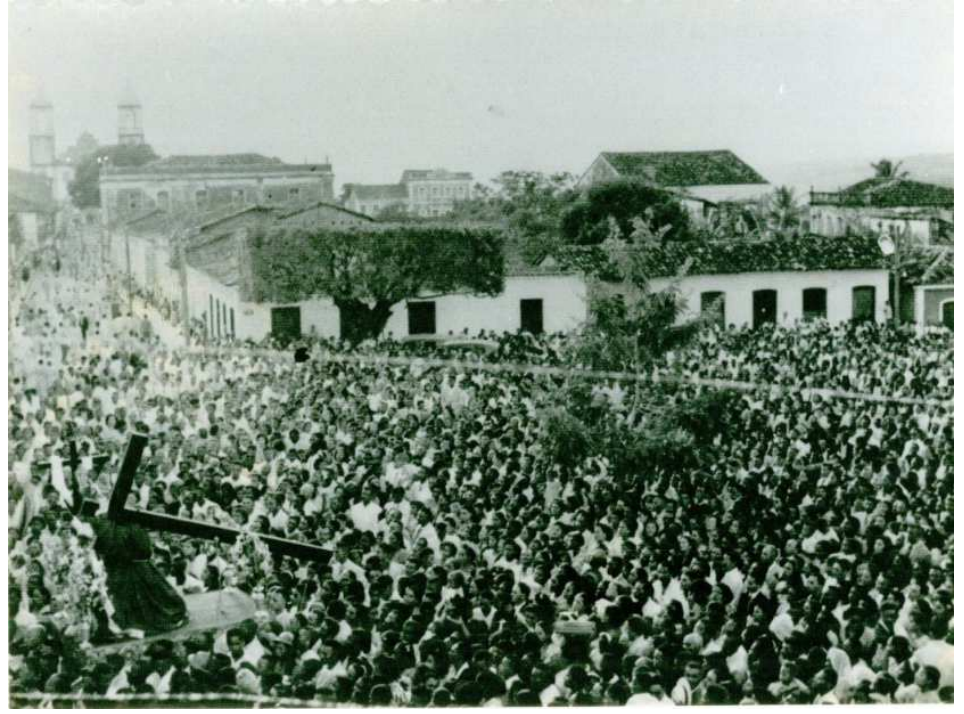

Fonte: Acervo Erundino Prado Júnior.

A praça transmutava-se em auditório, repleto de romeiros, muitos dos quais com feixes de lenha sobre as cabeças, vestidos em mortalhas roxas, pés descalços. Corpos mutilados no pagamento de promessas, para elevação espiritual. Romeiros com olhares atentos para as imagens, para o encontro de uma mãe com seu filho a caminho da morte. Romeiros que lotavam na praça, apinhavamse no intuito de manter aproximação da imagem, se ver a cena de dor, de jogar a túnica como forma de agradecer a graça atendida pela imagem tida como milagrosa. Nas mãos da imagem, vê-se fitas devocionais, ramos de flores, traços de túnicas deixadas pelos romeiros. Um momento de encontros litúrgicos, mas também devocionais.

A audição do sermão proferido pelo padre no púlpito da Praça São Francisco ocorria todos os anos na solenidade de Passos. A considerável multidão de devotos não impedia que as palavras penitenciais ecoassem por todos os cantos. Não eram somente os sinos que silenciavam, o público devoto fazia o mesmo, permanecendo contrito. Além do silêncio, também podia ser observado, no semblante dos romeiros, a emoção, através de lágrimas. Provavelmente, a emoção jorrava no momento em que o orador evocava os martírios do Cristo e da humanidade. Todos esses elementos estão no depoimento publicado do Correio de Aracaju de 1919: 
Deu-lhes lucinante destaque a palavra maviosa, correcta impressionante e convicta do illustre e talentoso sacerdote que se incumbiu do sermão do encontro da Virgem com seu Divino Filho, victima das injustiças da humanidade. Foi elle o revmo. Padre Constantino Sangremamm, virtuoso pároco da cidade de Itabaiana. Seu eloqüente sermão, em voz muito clara e vibrante de fé, foi tão elevado e tão digno do assumpto, que vimos muitos olhares marejados de lagrimas, quando o distincto orador e referiu as amarguras do coração materno, suppliciado pelas torturas do Grande martyr, principalmente no trecho margistral em que o illustrado pregador invocou os sentimentos affectivos das mães presente àquelle acto, verdadeiramente tocante. Apesar da cerimônia do encontro e da magnífica oração do sacerdote se darem na embocadura de uma das praças mais vastas da cidade, estava ella literalmente cheia e dominada pelo silêncio profundo, de modo que a palavra do digno ministro catholico foi ouvida por toda a multidão, em cujo seio vimos representantes de todas as classes sociais e de todos os departamentos da intelligencia, dede o inserito Presidentes do Estado até o humilde e obscuro homem do campo. (Correio de Araсаju, 19 mar. 1919)

Lágrimas, silêncio, emoção e aplausos eram uma constante na solenidade de Passos. Os cinco sentidos estavam atrelados ao evento religioso e podem ser usados como fio condutor entre passado e presente. Entretanto, a ordem nem sempre prevalecia. Em muitas ocasiões, o silêncio das celebrações era rompido por ruídos dissonantes. Os romeiros aquietavam-se na praça, observando o encontro para ouvir as palavras proferidas pelo sacerdote. Em meio ao silêncio do grande público, soavam descontraídas conversas paralelas. Portanto, nem todos os ouvidos estavam voltados para o sermão. Vejamos o novo enfoque do sermão.

\section{Figura 3: SERMÃo do ENCONTRO OBSERVAdo do CONVENTO SÃo FranCiSCO, DÉCADA DE 40 DO SÉCULO XX}

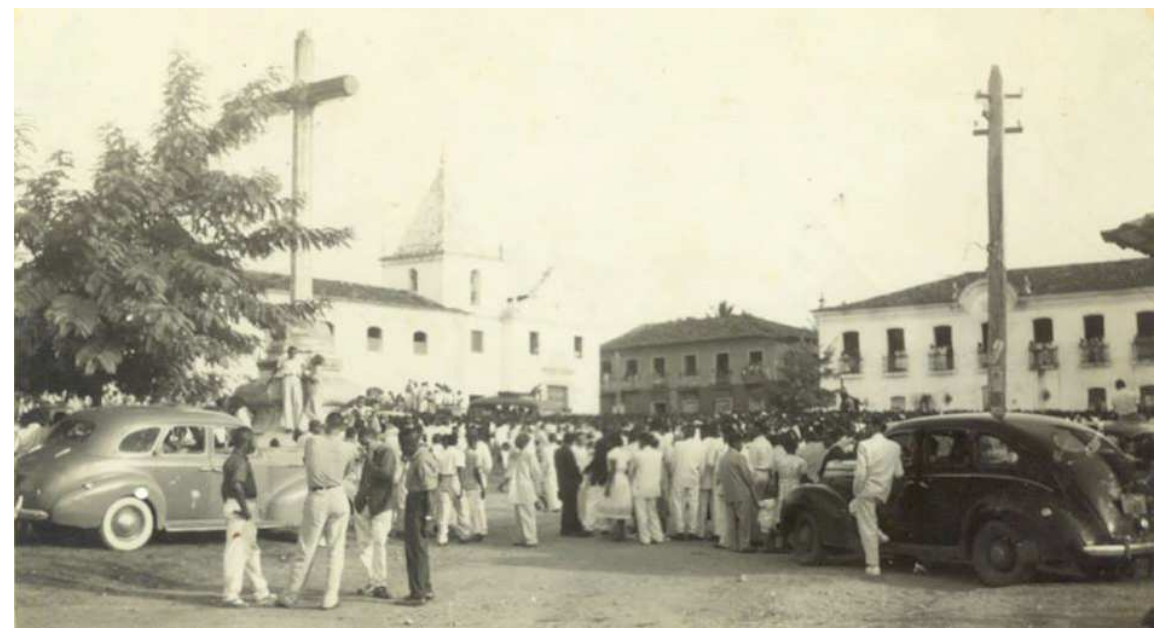

Fonte: Acervo Erundino Prado Júnior. 
O sermão do encontro era encerrado com o canto da Verônica. De forma teatral, uma jovem da cidade, vestida de túnica roxa, entoava o seu lamento abrindo e fechado um sudário com efígie do Cristo ensanguentado. Apesar de ser curto, o canto era executado demoradamente e de forma comovente, prendendo a atenção dos romeiros na Praça São Francisco. Serafim de Santiago, em seu anuário, a chamava de "Mulher-pia", nomenclatura instigante e que revela outras nuanças da solenidade. A partir das entrevistas com dona Marinete Paiva (2003) e Erundino Prado Júnior (2006), confirmamos algumas hipóteses. O triste lamento da Verônica só podia ser executado por mulheres virgens. Nos Passos sacralizados pelas ruas de São Cristóvão, o canto da Verônica ficava a cargo de uma jovem "pura". É importante salientar que, na teatralidade barroca dos Passos, a Verônica é a única santa-personagem da trama da Paixão que não é representada por imagens, mas sim por pessoas. Este é um forte indício da virgindade da intérprete, da Mulher-pia. Então a jovem entoava: "o vos ommes, que transites per viam, attendite, et videte, se est dolor sicut dolor meus" (Santiago, 2009, p. 189). Era "o canto dolorido da Verônica" (Diário da Manhã, 3 mar. 1917).

Ao final da apresentação da Verônica, os músicos cantavam "Miseri mei Deus, secundum magnam misericórdia tuan" (Santiago, 2009, p. 189), enquanto as confrarias acendiam seus tocheiros e os sinos começavam a dobrar. A procissão retornava a seu ritmo com todos os seus personagens: Senhor dos Passos, Nossa Senhora da Soledade, Mulher-pia, anjinhos, pálio e romeiros.

Figura 4: Saída das imagens do Senhor dos Passos e da Vigem da Soledade da PraÇa São Francisco. Detalhe Para a Verônica diante da charola da Virgem, 1950

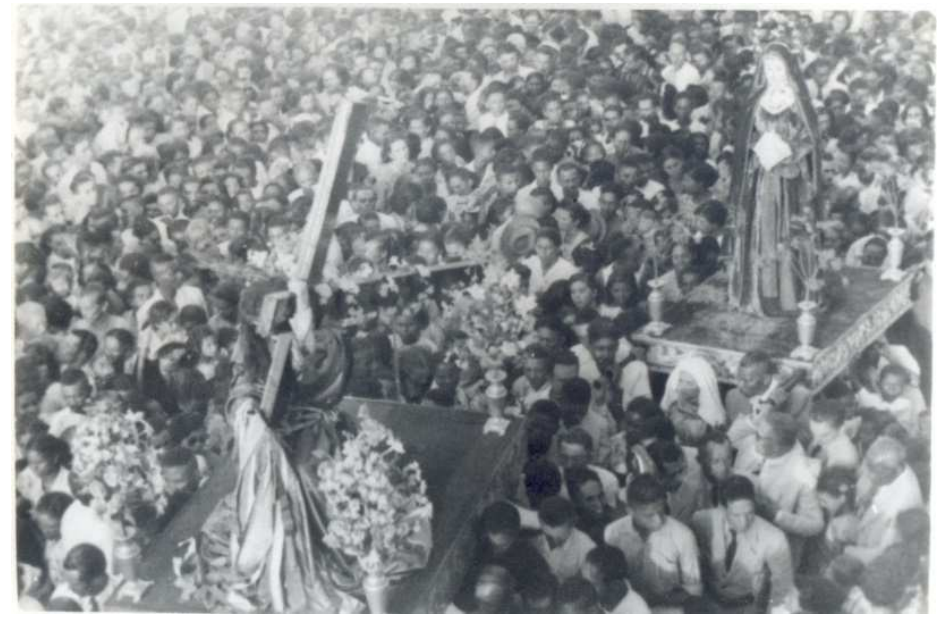

Fonte: acervo do autor. 
O Cristo ajoelhado com a pesada cruz sobre os ombros era transportado pelos devotos para o seu templo secular. Paralisada e ainda emocionada, a multidão presente no grande auditório cercado pelos monumentais templos e palácios, assistia ao lento deslocamento das imagens do Senhor dos Passos e da Virgem Dolorosa. Anunciando a saída do cortejo seguiam pela Rua da Cadeia duas fileiras de mulheres vestidas de branco, diacronicamente revivendo a presença das mulheres lacrimosas da Jerusalém bíblica e a demarcação do lugar social do Apostolado da Oração nas festas da Igreja renovada. Nas ruas estreitas de São Cristóvão, velhos personagens cruzavam os mesmos caminhos dos novos segmentos da esfera religiosa.

Ela ainda parava por três vezes até chegar ao alpendre do Carmo para o passo final. Ocorria então a despedida dos romeiros diante das imagens sagradas com o toque do manto, o beijo dos pés e fitas e os últimos dobres dos sinos. Com isso, "à noite, no Convento do Carmo foi grande a romaria de fiéis que iam diretamente beijar os pés das sagradas imagens" (Correio de Aracaju, 26 fev. 1918).

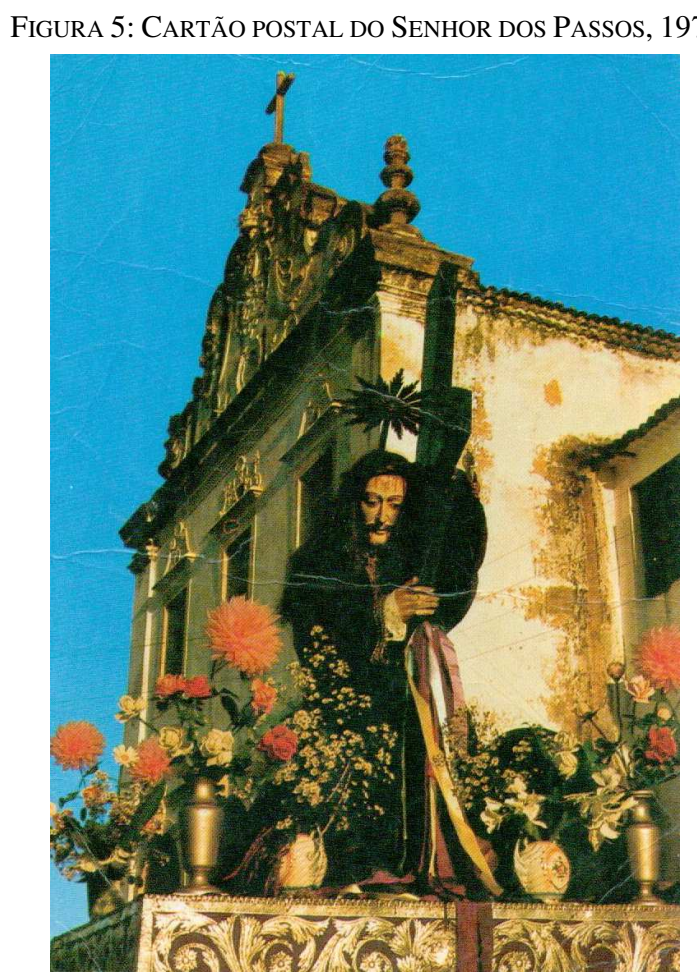

Fonte: Acervo Josefa de Jesus Santos. 
Diante da Igreja da Ordem Terceira do Carmo, os devotos contemplavam as imagens sobre os cavaletes e o dobrar do sino. Os últimos dobres representavam os momentos finais da permanência dos romeiros no espaço sacralizado. Os devotos esperavam a oportunidade de beijar os sagrados pés das esculturas ouvindo o ecoar das últimas badaladas sacralizadas, dos ruídos consagrados da cidade-santuário. A solenidade dos martírios do Salvador aproximava-se do final e os romeiros estavam prestes a retornar para a sua realidade ordinária (Eliade, 2001). O momento final da solenidade dos Passos era observado por diferentes ângulos, a depender da função do ator no enredo dos Passos. Os olhares cruzavam-se.

Porém, a despedida nem sempre pode ocorrer de forma tranquila e pacífica. Com a implantação do transporte ferroviário, a despedida do santuário tornou-se mais apressada para os romeiros que viajavam de trem. A contemplação demorada das imagens tidas como milagrosas permaneceu somente com os romeiros que usavam meios de transportes tradicionais (carroças, carros de boi, cavalos ou mesmo a pé). Pode-se dizer que, a partir da segunda metade da década de 1910, a solenidade passou a ter novos ritmos, mesclando inovação (pressa), com permanências (tranquilidade contemplativa). Assim, como todo o cortejo, a escultura do Senhor dos Passos era muito disputada pelos romeiros, que almejavam tocá-la e apreciá-la pela última vez.

Enquanto alguns devotos buscavam aproximar-se das charolas, outros apressavam em dirigir-se a Estação Ferroviária, pois "antes de recolher-se o préstito religioso já se ouvia o apitar contínuo da locomotiva, avisando a hora da partida" (Diário da Manhã, 10 fev. 1914).

Na Estação Ferroviária, a disputa por vagas nos trens da Chemins de Fer também era acirrada. Os empurrões eram constantes, sendo preciso a intervenção do corpo policial. O elevado contingente entre a estação e os vagões facilitava a prática de furtos, típico das grandes romarias. São ruídos dissonantes da celebração, os contrapassos da solenidade. Assim, enquanto os passageiros procuravam um lugar:

O gatuno pôz em prática um rápido roubo em bolso de um viajante, que, com certeza, já vinha assignado para a vistima, entregando-o ligeiramente a um companheiro que estava à janella do trem do lado de fora. Saltou pela janella o gatuno e vadiu-se com o outro, e o pobre passageiro roubado ficou se lastimando em meio a admiração de todos. (Diário da Manhã, 26 fev. 1918)

Os contratempos do retorno dos romeiros não se restringiam aos transtornos ocasionados pela superlotação dos trens. A viagem dos comboios da Chemins de Fer em algumas ocasiões ficava à deriva, à mercê da sorte. O perigo 
e os sustos também estavam presentes na solenidade de Passos. Um dos incidentes no retorno dos fiéis ocorreu com o vagão dos romeiros de Laranjeiras em 1918.

Além de outras coisas ordinarissimas da tal Chemins tivemos um grande susto. Um carro, dos muitos que conduziam passageiros para aqui e Laranjeiras, saltou do trilho e foi um Deus nos acuda. Depois de gritos e mais gritos dos passageiros foi que o machinista parou a machina e todos viram o perigo em que estavam. Foi uma viagem cheia de incidentes que felizmente não occasionaram perdas de vida graças ao Senhor dos Passos a quem todos tinham ido votar suas preces. (Diário da Manhã, 26 fev. 1918)

O retorno dos devotos nem sempre ocorria de forma pacífica. Os gritos desesperados dos passageiros demonstravam o pânico provocado pelo incidente, ou seja, o silêncio do cansaço dos romeiros cedia lugar à agonia. Mesmo assim, o fato de não ter havido vítimas fatais foi atribuído à intervenção milagrosa do Senhor dos Passos. O pacto firmado entre o devoto e o sagrado continuava em vigor. O Cristo com a cruz sobre os ombros continuava guiando os passos dos inúmeros fiéis nos caminhos da penitência.

\section{CONSIDERAÇÕES FINAIS}

Na procissão dos Passos os dramas sociais eram revividos. As dores dos excluídos expostas em público no processo identitário imagem/devoto. A cidade era transformada nas primeiras semanas da quaresma em palco do drama da Paixão de Cristo, no qual convergiam os moradores das localidades mais distantes. Com isso a festa fazia viver uma dramatização social. Nas procissões criava-se a possibilidade de recriar a história.

A romaria do Senhor dos Passos da cidade de São Cristóvão, mesmo constituindo-se como celebração de cunho oficial da Igreja Católica em Sergipe, ela deve ser vista sob a ótica do catolicismo popular. No período estudado (1903-1978), a Procissão dos Passos reunia em seus cortejos os mais importantes nomes da elite açucareira sergipana, que por alguns anos deteve o monopólio na trasladação das imagens. Contudo, o que a tornava principal solenidade religiosa sergipana era a maciça participação popular, com o depósito de ex-votos e com o cumprimento de penitências (Nunes \& Santos, 2005, p. 101).

Neste caso, a solenidade do Senhor dos Passos no período estudado pode ser vista como uma romaria, tendo em vista que a organização do evento estava a cargo dos irmãos terceiros do Carmo e contava com a ampla participação das camadas populares oriundas de diferentes municípios de Sergipe. O evento religioso do segundo final de semana da quaresma realizado todos os anos em São Cristóvão era uma cerimônia com forte inclinação para fora da alçada da hierar- 
quia eclesiástica. Essa constatação pode ser evidenciada ao se observar as críticas a esse tipo de celebração, registradas pelo clero da cidade no Livro de Tombo da Paróquia Nossa Senhora da Vitória.

Neste sentido, a força devocional da imagem tornou a romaria alvo de intensas disputas, envolvendo os frades franciscanos da Saxônia, que desejavam ter maior controle da celebração, dos recursos deixados pelos romeiros e, consequentemente, da oportunidade de empreender maior controle acerca das práticas devocionais. Por outro lado, os irmãos terceiros do Carmo foram os responsáveis pela manutenção da romaria entre o final do oitocentos e grande parte do século XX.

A procissão dos Passos de São Cristóvão é considerada a principal solenidade religiosa de Sergipe. Desde o século XIX, na segunda semana da quaresma, a cidade passava por um período de júbilo, regozijava com romeiros se deslocando dos mais variados recônditos no intuito de cumprir sua desobriga e renovar seus pedidos. Tratava-se de um evento que conseguia reunir em seu séquito tanto personalidades da elite açucareira do Cotinguiba e Vaza-barris, como pessoas anônimas, segmentos populares da sociedade sergipana. Esses atores históricos que teciam a trama festiva dos Passos não passaram imunes, pois foram alvo do fulcro ocular dos memorialistas.

Essas experiências foram analisadas por meio dos sentidos. É preciso lembrar que a história antes de ser registrada é sentida. Infelizmente, os historiadores ainda privilegiam exacerbadamente a visão em detrimento aos demais sentidos. Mesmo sem querer diminuir a relevância da visão como instrumento de percepção do mundo, deve ser lembrada a existência de outras formas de sentir a realidade vivida, seja pelo toque, pelo cheiro, pelos sabores ou pelo som. A história também é sentida e ouvida. Portanto, a romaria do Senhor dos Passos pode ser vista e entendida por meio de diferentes percepções da realidade, como os ruídos que sobreviveram às barreiras do tempo através do silêncio sepulcral dos documentos.

\section{BIBLIOGRAFIA}

Claval, P. (2001). A Geografia Cultural (2a ed.). Editora da UFSC.

Correio de Aracaju. (1918, 19 de março). Passos de S. Christovão. Correio de Aracaju, p. 3.

Correio de Aracaju. (1919, 26 de fevereiro). Passos. Correio de Aracaju, p. 2.

Diário da Manhã. (1914, 10 de fevereiro). Senhor dos Passos. Diário da Manhã, p. 3.

Diário da Manhã. (1914, 10 de março). Festa dos Passos. Diário da Manhã, p. 2.

Diário da Manhã. (1916, 19 de março). Passos em S. Christóvão. Diário da Manhã, p. 3.

Diário da Manhã. (1917, 3 de março). Passos. Diário da Manhã, p. 3. 
Diário da Manhã (1918, 26 de fevereiro). Festas do Senhor dos Passos em S. Christóvão. Diário da Manhã, p. 2.

Duvinaud, J. (1983). Festas e civilizações. UFCE.

Eliade, M. (2001). O Sagrado e o Profano: a essência das Religiões. Martins Fontes.

Ginzburg, C. (1987). O queijo e os vermes: o cotidiano e as idéias de um moleiro perseguido pela Inquisição. Companhia das Letras.

Freyre, G. (2000). Ordem e Progresso (5 $5^{\mathrm{a}}$ ed.). Record.

Monteiro, M. P. (2013). Entrevista concedida ao autor no dia 12 de dezembro de 2003. São Cristóvão.

Nunes, V., \& Santos M. (2005) "Na trilha dos Passos do Senhor: a devoção ao Senhor dos Passos de São Cristóvão/SE". Revista da Fapese. (pp. 97-110).

Santiago, S. de S. (2009). Annuario Christovense. Editora UFS.

Thompson, E. P. (2007). Folclore, antropologia e História Social. In E. P. Thompson (org.), As peculiaridades dos ingleses e outros artigos (pp. 227-268). Unicamp.

Tombo. (1979). Livro de Tombo da Paróquia Nossa Senhora da Vitória. Paróquia Nossa Senhora da Vitória de São Cristóvão.

Tuner, V. W. (1986). Imagem e Peregrinação na Cultura Cristã: um esboço introdutório. Centro Editorial e Didático da UFBA.

Vovelle, M. (1987). Ideologias e Mentalidades. Brasiliense. 